\title{
Work requirements, expenditures, and labor supply decisions: Evidence from Malawi
}

\author{
Kate Ambler and Susan Godlonton
}

A major goal of social protection programs run by governments and NGOs in the developing world is to provide income support to individual and households living in poverty. These programs tend to be split between cash transfer programs that provide cash to families with no conditions, and public works programs that require participants to work in order to receive the cash payments. Despite the widespread nature of both types of programs, and large literatures that examine their impacts, there exists little work directly comparing them. Such a comparison would be useful to policy makers considering whether a cash transfer or public works program better meets their goals.

There are many reasons to imagine that the impacts of cash transfers and public works programs might differ. Although standard economic models dictate that money should be fungible, there is extensive support for the theory of "mental accounting," which posits that people may have different buckets for money that comes from different sources, and thus spend that money in different ways. Money considered to be a windfall for example may be spent more easily on temptation goods, while money that is part of a permanent income stream may be reserved for more subsistence type purchases. Earned and unearned money could similarly be assigned to different mental accounts.

Work requirements may also impact the labor supply decisions of those who receive money. In particular, participants may receive information from the experience of working that affects their subsequent choices. This information could be related to their skills and taste for wage work. It could also be information regarding the labor market itself coming from the experience of working together with others.

The difference between earned and unearned income has been studied experimentally in the laboratory, primarily as it relates to the measurement of pro-social preferences. Very little work studies this difference in actual expenditure and work habits in the real-world environment. One difficulty is that the distinction between earned and unearned work is usually conflated with other differences, namely that unearned income is more likely to be windfall income, and that earned income implies a time commitment that unearned income does not. In this project we studied whether earning versus not earning a cash payment led to different allocations of real-life expenditures and labor supply, holding these other 
factors constant. Our study takes place in Malawi, a country with extensive social protection programs, including both cash transfer and public works programs.

\section{Experiment and results}

Participants attended one of a series of day-long events, in which they were given 2,000 MWK for attendance, and 8,000 MWK additional for completing the day's events. Participants were randomized into two groups: those for whom the activities consisted of waiting to complete a baseline survey, and those for whom the activities consisted of work, namely classifying newspaper articles into themes and transcribing those articles. Both groups spent the same amount of time at the event, and in both cases the payment was a windfall. The only difference between the two groups was the work requirement. Following the events, we collect information on expenditures and labor supply, once a week for three weeks via a series of phone surveys.

Our results indicate that those participants who earned the cash payment did not reallocate their expenditures relative to baseline expenditures differently than those who were not required to work. We did however find that they spent more overall in the first week following the events (but not in the subsequent weeks). When examining labor supply, we find that those in the earned group reallocated their labor supply significantly more relative to baseline than those randomized into the unearned payment groups in the first week following the events only. Specifically, they work significantly less in household economic activities, both agricultural and non-agricultural. We hypothesize that participants in the earned group may be spending more time both looking for and doing wage labor, inspired by the experience they had working at the events. They may have used their payment to stake this job search, as evidenced by the higher overall expenditures, and returned to household activities when they were unsuccessful in locating work. This interpretation is however speculative and must be verified by future research.

See our associated working paper here.

\section{ABOUT THE AUTHORS}

Kate Ambler is a Research Fellow at IFPRI's Markets, Trade and Institutions Division.

Susan Godlonton is an Assistant Professor at the Williams College Economics Department.

Funding for this work was provided by IFPRI Strategic Innovation Fund, the CGIAR Program on Policies Institutions and Markets, and DFID Brazil. This publication has not been independently peer reviewed. Any opinions expressed here belong to the author(s) and are not necessarily representative of or endorsed by IFPRI. 